\title{
Literature as Study and Resource: The Purposes of English Literature Teaching at University Level
}

\author{
Juan Jesús Zaro Vera \\ Universidad de Málaga
}

\begin{abstract}
This paper attempts to examine the two main purposes of the teaching of English literature at university level in an EFL situation. The first, literature as study, is divided into two options. One is the type of teaching that considers literature as a cultural product for whose interpretation aspects outside the literary work (historical, social, critical, biographical data) must be accounted for. The other is the stylistics option, dealing with the analysis of literary texts by examining their language. The second general purpose is the recent widespread use of literature as a resource for the teaching of the English language. In our opinion, it is the EFL environment which allows the implementation of the two aims, whose goals and methods are closely interlinked, providing as well a connection between the teaching of language and litcrature. Some suggestions for this implementation are offered in the specific case of Spanish universities.
\end{abstract}

Literature, as a school and university discipline, has traditionally enjoyed a high status that has in a way hindered a discussion on its objectives, methods and possibilities as a subject, which have mostly remained untouched for years. Discussion that, on the other hand, has affected many other less-favoured subjects. Some new proposals, however, have recently been put forward in the case of literature taught in EFL situations. In this special domain, literature is invested with a singularity lending itself to prospects barely explored so far. The debate has led to the publication of quite a number of recent titles dealing with the subject, which mostly tend to consider the teaching of literature from two different points of view: (1) as a discipline, to be studied as a cultural product, and (2) as a resource for language learning, this latter being the latest. This is the case of, for instance, Alan Maley, author of a considerable number of titles using literature merely as a language resource. However, Alan Maley, in this same article, distinguishes two possible approaches in the first case: (1) the study of literature from a «literary critical approach,» or traditional approach focusing on the «literariness» of the texts (on plot, characterization, motivation, value, background, etc.) and whose main objective is the interpretation of literary productions, and (2) the stylistic 
approach, in which the focus is on the text (24). This second approach aims to make textual discoveries leading to descriptions such as parallelism, deviancy, prominence, etc, upon which interpretation can be based. In this case too, linguistic elucidation (as the approach resorts mainly to a linguistic analysis of the text) precedes interpretation. The book to which most British stylistic critics refer to as the starting-point of the new approach is undoubtedly Henry Widdowson's Stylistics and the Teaching of Literature (1975), while Mr. Maley quotes Style in Fiction by Leech and Short as a perfect example of applied stylistics.

There have been other attempts to classify the study of literature, as for example, Pickett's proposal for two different literature syllabuses to cater for the needs of fast and slow readers. Pickett suggests the study of «intensive» or «analytical» literature, as well as of «extensive» or «accumulative» (270). These two kinds of studies have been very well-known for a long time in the field of applied linguistics, both being necessary for the development of the reading skill. Within literature teaching, both reading modes are usually present, be it a stylistics or a mainstream literature class. Stylistics has definitely gained a place in literature teaching and certainly a remarkable diffusion in terms of bibliography and research over the past twenty years. In Spain, it is now a subject in several universities within the «Filología Inglesa» curriculum, and has been included in most of the proposals for credit requirements leading to the diploma of «licenciado». ${ }^{1}$ All these factors contribute to considering this approach as a third option in our discussion on the purposes of literature teaching at university level. Therefore, literature is a subject which for teaching purposes may be divided into three options: (1) as a discipline, to be studied as a cultural product («mainstream» option); (2) as a source of materials (texts) to be analysed from a stylistic point of view; (3) as a resource for language learning. I will now proceed to discuss the characteristics of these three options in the light of the contribution of experts on this matter and my own personal experience:

1. Option 1 is what has traditionally been regarded as «the teaching of literature,» that is, a study of plot, characterization, motivation, etc, and also, sometimes overwhelmingly so, a study of the author and their historical and literary background. Lecturing has always been the prevailing teaching procedure. Students take notes, make comments and eventually take tests or exams on the lectures and readings prescribed by the teacher. The reading mode is extensive, although extracts from the works studied can be analysed in the classroom. Lessons are therefore teacher-centred and the whole process tends to be transmissive and product-centred in the sense that the final outcome (usually, a logical, sound interpretation of the works handled), is that expected. This, more or less, is the tradition in European universities, and certainly the case of literature teaching, in general, in Spanish universities. H. L. B. Moody still claims a difference between the British and the rest of the Europeans in the sense that the British «have always rejected the kind of outline course, popular in some parts of the world, in which students acquire many facts about authors and works of literature without ever gaining first-hand experience of any of them» (91). On the other hand, the American tradition has concentrated on the effects of the literary work on the reader much more than on the work itself. This tradition is rooted in the works of philosophers and educators such as John Dewey and George Santayana, and in the literary field was established by critics like I. A. Richards, who developed the concept of «emotional response» in the 
1920s, D. W. Harding, and especially Louise M. Rosenblatt, whose book Literature as Exploration signals the beginning of a new phase in the teaching of literature in the United States at all levels which rates the individuality and creativity of the reader and the experience derived from reading much higher than a studied and well-grounded interpretation of the literary work.

From a purely pedagogical point of view, both traditions have advantages and shortcomings. With the European, one of the problems is that students tend to rely too much on the teacher and other external authorities (books, articles) outside themselves. In the United States, the reader's response is generally overestimated and any other background information is just not considered pertinent. I think that in this point some balance is needed, much more so at university level, where students must cope with all kinds of literary works which, specially the older ones, very often demand the knowledge of contextual clues to be fully understood. But at the same time it is a fact that in an excessively academic situation students gradually lose their self-confidence as their individual critical points of view are never expressed and therefore, cannot be assessed by the teacher. In any case, my belief is that first, the enjoyment, and later the study of literature involve elements outside the literary work which have to be accounted for specifically at all teaching levels. The concept of «literary competence,» as defined by Jonathan Culler (Structuralist Poetics 113-30) reflects this assertion perfectly well. Culler argues that «reading is not an innocent activity ... it is charged with artifice» (129), implying that a good reader is something more than just a spontaneous and creative individual. More recently, Christopher Brumfit has defined this notion more extensively: It requires some linguistic sophistication, as well as a degree of familiarity with particular cultural conventions, and finally, it involves a recognition that languages can be used in a deliberately irresponsible way to create metaphorical meanings that illuminate our self awareness (Literature and Language 45-49).

The process of developing this competence is of course more difficult to establish in the case of students whose native language is not English. Although some of the features defining «literary competence» seem of course transferable from one's native language literature to another, understanding the foreign language will always constitute a major obstacle. In these cases, the need of a sound knowledge of the language in question should perhaps be the first requirement. Pickett writes: «to be biliteral [meaning the possibility of understanding and enjoying literature written in two languages] is much rarer than being bilingual» (271). The merits and real value of this «literary competence» are also a question for discussion within the field of literary criticism, brought about mainly by deconstructionism and post-structuralism. Both these movements have some of their roots in linguistics, the former in the theories of C. S. Peirce and the Sapir-Whorf hypothesis of «linguistic relativism,» and the latter in Saussure. Their concepts are also connected with the ideas of scientists like Ludwik Fleck, who introduced the notion that subjective and sociological factors play a decisive role in scientific development.

To deconstructionists, reality did not exist prior to language. Literature and science are socially and culturally constructed versions of the real. There is no objectivity of literary texts. The notion of «literary competence,» therefore, is illusory and deceiving since the reader, but also the critic, is always ideologically situated. A critical judgement, no matter how sophisticated the critic, is always an «interested» activity, as 
partial or biased as the judgement of any other reader, since it only reflects «a set of conventions that directs the reader to pick out certain features of the work corresponding to public notions of what constitutes acceptable or appropiate interpretation» according to Jane Tompkins («Introduction» 8). Deconstructionists reject the «academic» interpretation of the text on the grounds that it is the result of particular interpretative strategies originated in an institutional context probably dictated by political motives. In this sense, their proposal is «to perceive language as a form of power» (Tompkins «The Reader in History» 226). To deconstruct, they scrutinize and analyse texts by reading them closely and attentively, entering a free play of interpretation that never aspires to achieve a final totalizing of meaning. In On Deconstruction: Theory and Practice After Structuralism, Jonathan Culler mentions the great confusion that this theoretical debate brought about in American universities (17), and the accusation of other critics that «graduate students [are] mechanically imitating what lies beyond their reach» (227). Deconstruction is not a technique, susceptible to mechanical repetition, and to become a teaching method has certainly never been one of its goals. Therefore its implantation as an academic approach is, by definition, meaningless, at least at undergraduate and graduate levels or their equivalents. The detailed verbal analysis that it demands and some of the strategies that their specific close reading entails, like «scrupulous atteniion to what seems ancillary or resistant to understanding ... to the rhetorical mode or status of important details...to structures that resist a text's unifying narrative scheme» (Culler On Deconstruction 251) have made some critics judge it as simply a «playful academic exercise ${ }^{2}$ that requires a great amount of linguistic and literary sophistication on the part of the reader which is not easy to find among graduate students. Although the concept of «literary competence»-in so far as it leads to academic interpretation-is suspicious for deconstructionists, the linguistic and contextual studies which it implies certainly help them to gain an insight into the works that they examine. In short, this debate can not be directly connected with our discussion on the teaching of literature except for two aspects. First, the work of these new critics will surely have to be taken into account for the study of specific literary works (e.g. Walter Michael's «Walden's False Bottoms,» Barbara Johnson's discussion of Billy Budd, etc.), and second, the fact that deconstruction as a critical attitude can lead to revealing findings that mak: it an interesting approach for literary research, even though it never aspired to become so.

In my opinion, the main objective of this option of literature teaching should be the development of literary competence, which cannot consist simply of exposure to literature, but must include studies of literature (Hasan Linguistics, Language 104). This involves not only a considerable amount of reading of literary works but also of referential and contextual information. Students should also gain at leas $\hat{\imath}$ an outline knowledge of the literary history of the language in question. How much of these activities, which ones and in which order are the big questions that departments of literature must decide upon. Other pedagogical issues, perhaps seldom dealt with by literature teachers, are, for example, assessment and testing procedures and teaching methods, this latter being reduced sometim, as we mentioned earlier, entirely to lecturing. Very often, the absence of clear guidelines about what to do makes literature students complain that they would be much more effective academically if teachers were clear about what is expected of them. But to refer back to the development of literary competence, perhaps the best outcome of being literarily competent lies in the 
open possibility of enjoying reading and being able to judge a literary work, once studies have finished.

2. Option 2 is the very well-known «stylistics» option. As we mentioned above, the book which is regarded as the «seminal» work for this kind of literature teaching is Henry Widdowson's Stylistics and the Teaching of Literature (1975), although the term «stylistics» is much older than that. In this book, Widdowson listed some reasons to implement stylistic studies. One is that few students go on to do literary research, so there is no need to train them to be literary critics, but rather to provide a basis for developing their interest and enjoyment of literature (3). On the other hand, in the case of literature studied exclusively for cultural purposes, his reasoning is that there seems little reason why it should not be in translation (78). Finally, he argues that in traditional literature teaching, there is, generally, very small participation of the students (82). Even though Stylistics has been regarded as a reaction against impressionism, Widdowson admits that stylistic analyses are ultimately based on intuitions, «which it is the purpose of literary scholarship to develop» (1). Geoffrey Leech also admits that it is wrong to expect linguistics to provide an objective, mechanical technique of analysis which can replace the reader's intuition (Style in Fiction 5). However, he advocates a thoughtful, systematic way to the study of literature which can include the contribution of the most recent developments in the fields of applied linguistics, sociolinguistics and psycholinguistics. In this manner, by detailed analysis, intuitions may be checked or validated. It is this belief that understanding about language has direct consequences for understanding the meanings of the work of literature, that interpretations are often not simple intuitions but language functions, which differentiates modern stylistics from previous critical approaches like the «New Criticism» or «Practical Criticism.» Of these it preserves their interest in the detailed textual analysis of literary works, described by the eminent critic Leo Spitzer with the notion of the «philological circle,» still a valid image for the method to be followed. Stylistics experts consider themselves as inheritors of the study of Rhetoric, not in its prescriptive, but rather its descriptive sense. The aim of stylistics is not as much the interpretation but the explanation and appreciation of the literary work.

Within the field of stylistics, different methods can be mentioned: (1) The contribution of generative grammar. The old opposition of «surface» versus «deep» structure led some experts, like Richard Ohmann (423-39), to consider the concept of «style» as equal to «choice of expressions.» This made possible a «de-transforming» technique consisting of the study of what an author has actually written as opposed to what he might have written. His most famous example is a passage from a short story by William Faulkner, The Bear, still used in American universities, which Ohmann compares to the same «detransformed» passage in which he eliminates the transformations used to form coordinated sentences, relative clauses and comparative clauses, the point being that Faulkner's style is precisely characterized by a heavy use of these transformations. (2) The Halliday-Hasan approach, sometimes known as «study of verbal art,» derived from the work of M. A. K. Halliday. «Verbal art» is considered to be a semiotic system with an internal design similar to that of the semiotic system of language. If human language is a multiple coding system consisting of three strata (semantics, lexico-grammar and phonology), there are also three strata in verbal art: theme, symbolic articulation and verbalisation, all three of which are to be accounted 
for in text analysis. Nevertheless, the stratum of symbolic articulation is the main object of study since it is here where the meanings of language are turned into signs having a deeper meaning. The old notion of «de-automatization» of the linguistic code or «foregrounding,» developed by the Prague school of Poetics, and patterning of patterns, are devices playing an important role in this process. Yet Hasan points out, finally, that literature is not a self-motivated activity divorced from the concerns of the community in which it is created, and stresses the importance of the context to account fully for the meanings of the text (98-100). (3) The pragmatics contribution, developed, among others, by J. R. Searle and H. P. Grice. Pragmatics studies the «intended speaker meaning," that is, the way utterances are used and how they relate to the context in which they are uttered. A key term in pragmatics is the «speech act,» which is the type of «act» performed by the speaker in uttering a sentence. The analysis of these «speech acts» and the role of deictic words is sometimes crucial to the analysis of poems and novels. On the other hand, H. P. Grice developed the concept of «implicature,» that is, the meaning we infer from what is openly said in plain language (23-65). As Leech points out, this concept is the basis, in ordinary conversation, of traditional rhetorical figures such as metaphor, hyperbole and irony (Style in Fiction 299). (4) The British school, represented by the work of Geoffrey Leech and other scholars (Michael H. Short, Norman Page, Roger Fowler). Leech defines stylistics as «the study of the use of language in literature» (Style in Fiction 2) and so his two major contributory books $A$ Linguistic Guide to English Poetry and Style in Fiction, written jointly with Michael H. Short, are comprehensive linguistic approaches to the study of poetry and narrative fiction.

Other approaches to the study of literary productions, not directly concerned with stylistics in the Anglo-American sense, such as the methods of the European structuralist school, divulged in the Anglo-Saxon world by the work of Jonathan Culler especially, should be mentioned. This school, predominantly French and with such eminent representatives as Roland Barthes, A. J. Greimas, Tzvetan Todorov, Gérard Genette and Julia Kristeva, considers itself as the inheritor of the Russian formalist school. Its priority is basically the analysis of the syntactic level of narratives intending to establish a «grammar of narration.» Greimas, for instance, aims to construct a narrative grammar from which basic plot paradigms and other categories like the six «actants,» would form a mechanism generating the performance of stories. Tzvetan Todorov, on the other hand, devised two units of structure, propositions and sequences, for the analysis of plots in narratives. Finally, the approach designed by the American William Labov is also connected with the study of narrative structure. Labov extrapolated six structural properties (abstract, orientation, complicating action, evaluation, resolution and coda) which do not necessarily have to proceed in this order. This model is mostly applied to the study of short stories.

The stylistic approach, however, has been subject to severe criticism by other scholars. C. J. Brumfit and R. A. Carter, although believing that students and teachers of literature should engage in stylistic analysis, acknowledge some limitations to this procedure. They argue that stylistic analysis cannot be the only approach to the study of literature, and that linguistics, as a descriptive science, cannot account for the significance of texts, since literature is a discourse involving more than mere systems of language (4). Gower argues that stylistics is often too mechanistic and reduces the literary artifact to a linguistic model. Walker and Carter also express some limitations 
to the use of stylistics. For example, its a-historical sense, failing to take account of historical determinants on meaning, and its product-centred character, considering the text as holistic and untouchable, opposed to the current teaching theory and practice which is more concerned with process and considers that texts are not stable or fixed entities (64-78). Finally, the processes by which stylistics seeks out interpretations have also prompted the critique of post-structuralism and deconstruction that language will always overrun any determinate interpretation you put on it (224-240). All these objections, in my opinion, do not undermine the intrinsic value of stylistics as an approach to the study of literary texts. It cannot be the only approach to literature, but nowhere have the stylisticians tried to consider stylistics as the only possible option. In our situation, the value of stylistics lies also in its bridging the gap, sometimes wide, between language and literature existing in our universities, and in its capacity for developing the analytical powers of our students, as it makes them base their arguments on linguistic elements, avoiding the well-known gibberish of some students when it comes to talking about literature. Besides, from our point of view as teachers we must not lose sight of the fact that non-native students of English have some advantage in the sense that they have learned how to analyse sentences grammatically and have some awareness of the English phonological system. They are, therefore, «better equipped to analyse literary language and its relationship to meaning than today's average native-speaking undergraduate student of English» (Brumfit and Carter 93).

3. Option 3 is literature as a resource to develop linguistic competence. The use of literature as a medium for language acquisition purposes rather than as an object of literary analysis is fairly new. This can be seen by the recent publication of books on this subject (Brumfit and Carter Literature and Language Teaching, Collie and Slater, Literature in the Language Classroom). Traditionally, the idea that literature, especially prose texts, could be used for linguistic purposes was always associated with some kind of literary analysis so that both were considered inseparable. This was generally the case of foreign language textbooks, which usually included non-simplified literary selections. In other cases, the reading and analysis of full literary works was prescribed. This practice has been the rule, for example, in Great Britain in the case of the A level foreign languages exam. The recent success of the first students to take this exam since the implantation of the GCSE studies has however been attributed to the «less emphasis on literary, studies» contained in the new A-level syllabuses (Ward 22). In strict EFL situations, one of the most decisive factors that has put an end to this trend, and with it to the «sacrosanct» treatment of literature, was the widespread use of simplified readers. The first simplified readers were published in the forties and fifties, mostly based on famous novels or stories, the underlying assumption being that if the story itself was appealing enough for the student, the book would make a useful source of vocabulary and linguistic input. Still today, second language researchers advocate the use of simplified readers on the grounds that (1) their simplified register can be tuned to the basic English of the student so that the text becomes a source of comprehensible input, and (2) if the stories are attractive enough, the act of reading becomes pleasurable and the student will be likely to read more and, consequently, get much more input on his own, in a relaxed and anxiety-free situation very favourable for the acquisition of a foreign language (Krashen 38). Simplified readers have nowadays become an established «supplementary activity» at all levels, in which the undisputed literary origin 
of many of them does not imply any «literary» approach any longer. Many of them are not even adaptations of literary works. They have been written on purpose to be just what they are by professional authors, some of whose names (Norman Whitney, L G. Alexander, Peter Viney and others) are usually associated with some other aspects within the EFL busy publishing market.

From our point of view as English literature teachers working in universities with non-native students, it should be said that this constant interaction between language and literature is always, often unconsciously, present. The lack of sufficient comprehension and fluency on the part of students often makes it necessary to resort to activities such as explanation, paraphrasing, retelling, or translation, which constitute sound language practice. In the case of examinations or written assignments, the poor quality of the students' language may distort the content or simply prevent them from conveying it properly. Their mistakes are normally marked and penalized. If we use English in our lessons, the common assumption among our students is that the literature class is, apart from its intrinsic character, another source from which language can be learnt. This can be explained because it is a perfect «sheltered» class that provides a subject-matter with a definite content in which the four skills can be practised. It is something of a paradox that this meaningful language exchange sometimes does not always occur in a proper language class, where the target language is the object of explanation and both chances and topics to talk about or discuss in English can be more difficult to find.

It is not altogether preposterous, then, to resort to literature in order to promote language acquisition. In foreign language studies, we could speak of it as being an unavoidable corollary not only of literature teaching, but of any other «content» subject taught in that foreign language. The above description is a reality in our universities, and its consequences should be assessed both by language and literature teachers. But at the same time, the possibilities of literature to improve linguistic competence as intended in option 3 should not be underestimated. Reading in general is, as I mentioned before, a wonderful source of input. It is an essential activity recommended at all levels of learning, since it always provides chances to learn new words and gain awareness of the language. Followed by some further exploitation, it may even constitute a language teaching method. The «reconstructive» strategy of language teaching, very recently rescued from oblivion by Waldemar Marton is based on the reconstructive or modelling principle which includes memorizing of texts, retranslation and reinterpretation, and substitution and extension of the original sentences, all of them activities that are feasible using, for instance, short stories (57-81). The method is successfully utilized to teach foreign languages to adults in eastern European countries. On the other hand, research has shown that reading input is paramount in order to obtain competence in writing. Writing practice and instruction by themselves will not help writers acquire the code. There is published evidence for this in the case of native language, and one might expect a similar relationship to hold between reading and writing in a second language (Krashen 38 ).

But why use literary texts (novels, short stories) instead of other written material ? Some reasons have been put forward by experts in this field. William Littlewood, among others, argues that literature is a perfect vehicle for the learning of differences between language varieties and also of a foreign culture (181). Another advantage is that literature creates subject-matter and provides «content» material which can be 
catalogued as «authentic» even though it does not reflect direct experience. And finally, perhaps the most important aspect is that literature has suggestive power and enough ambiguity so as to start discussions and opinion exchanges among students. This last advantage is highly considered in the language teaching field nowadays given the lack of opportunities that a foreign language teacher has to carry out real or meaningful language exchange between students and teacher or among the students themselves in such an extreme conventional place as the classroom. Other advantages, like the possibility of using «localized literature,» that is, literature that contains content, settings, cultural assumptions, situations, etc, that are familiar to the second-language reader, to take advantage of their previous background knowledge or «schemata» (Brock 22-26), do not seem very relevant at university level, although must be taken into account at other stages. However, it hardly seems necessary to point out that not every literary text is suitable for this kind of activity. In this respect, Brumfit and Carter assert that «there is no such thing as literary language» on the grounds that no single or special property of language is exclusive to a literary work (25). This might be certain, but even they admit that sometimes language is used in ways that can be distinguished as literary, and which would be pointless to exploit in a classroom putting aside its specific literary condition. The first premise is consequently that texts intended to be used for language purposes should be carefully selected by criteria of «interest» rather than «literariness.» Short and Candlin propose two other criteria for this selection: that texts should have (1) density of meaning and (2) a high degree of inferability (109). What is, of course, also necessary is a well-read teacher with sensibility and experience, in other words, with knowledge both of an ample body of literary works and of their students' interests and expectations.

As with options 1 and 2, the notions of «extensive» and «intensive» reading can also be applied here, but with exclusively linguistic purposes. One possibility is an extensive literature reading programme (of non-simplified novels or short stories) with the aims of improving the reading skills of students and enhancing their vocabulary. Two versions are feasible, one interventionist, offering a given list of books which all students must read and then be tested on, and another non-interventionist, allowing the individualization of reading assignments: students choose the books themselves and then write a standard «reading questionnaire.» Likewise we can speak of «intensive» reading activities using literary texts in a language class, which would of course differ from the tasks to be carried out in a literature class. They are basically student-centred activities taking advantage of the indeterminacies of the text as mentioned before, like discussions, opinion polls, etc. Other more traditional activities (cloze, re-writing, prediction, note-taking, role-playing, summaries) can also be implemented, including the intensive classroom study of a novel, a play or a collection of short stories.

\section{Conclusions}

The need to relate linguistics and literature has prompted a debate which has given rise to proposals for the implementation of new instructional programmes aiming to explore the connections between the two domains (e. g., the programme in literary linguistics at the University of Strathclyde). ${ }^{3}$ In an EFL situation like the Spanish one, the dilemma «language or literature» at university and further education levels is sometimes 
associated with the debate «academic» versus «non-academic» that occurred in the United Kingdom between polytechnics and universities a few years ago. Of course it does not only affect literature, but also the academic study of language usually carried out in our universities. The discussion must surely take place here sooner or later. It is to be expected that new careers in English, or any other foreign language, will not include a very extensive study of literature, if at all. The study of language will be primarily intended to meet specific purposes, without an academically-oriented description, which is perfectly understandable and legitimate in this type of studies. However, the inclusion of option 3 (literature as resource) is possible in some of these cases.

Therefore, it is to be assumed that «Filología Inglesa» studies will be the only ones comprising the disciplines of literature and language with a definite academic orientation, both of which should be present all the time in one way or another. Nevertheless, very often they seem to be disconnected, a situation that should be avoided for their mutual benefit. For instance, the implementation of option 3 in the shape of an extensive reading scheme at early stages would promote not only language acquisition but also the habit of reading that students need for their literature courses at graduate level. The stylistics option, on the other hand, requires elements belonging to both domains, acting as a useful mediator. We can conclude, therefore, that options 2 and 3 have merits to be included in English language and literature curriculums at university level, even if it is to a different extent from the mainstream literature courses represented by option 1 . To end with, I include a couple of suggestions for the implementation of the three options mentioned in this article:

Option 3, literature as resource, can be included in initial university courses, as part of the English language syllabus, because it is at this stage when the linguistic abilities and skills of students need to be increased, Two possibilities are:

1. An extensive reading programme, composed of non-simplified short stories or novels, which can be either interventionist, non- interventionist or both, with the aims expressed above: to help students improve their reading skills in English (which might be very elementary due to insufficient reading practice in English in primary and secondary schools), to increase their vocabulary, and to improve their writing skills. And last, but by no means least, to give students the experience of reading that they must develop to go on to a further «account» of that experience, as carried out by options 1 and 2.

2. The frequent use of short stories in the classroom, in this case much more in terms of what is called «intensive reading» in foreign language teaching, using the strategies and exploitation techniques suggested above. Luckily, the repertoire of short stories in Anglo-American literature is very extensive, so there is plenty to choose from. No literary analysis has to be carried out in this option, but rather a solely linguistic exploitation of materials. The two alternatives will certainly require some kind of grading depending on the level of the students, which implies first the knowledge of their linguistic skills (not an easy task, at all) and secondly, a careful selection of the works to be read. The use of literature resources in other subjects such as, for instance, «cultural» approaches is also feasible, although Brumfit and Carter point out the difficulty of viewing literary works as «pictures» of British or American life, since the language and the content of literature is deliberately and creatively modified (sometimes even distorted) for the needs of the writer (25). 
Options 2 and 3, literature as study, should both take place from the third year onwards. It does not make much sense to include them at an earlier stage, when students do not have enough linguistic competence. As we have said earlier, developing the literary competence of students should be the ultimate goal of the «mainstream» literature courses, rather than trying to acquaint them with a loose, unrelated bunch of authors or works. A comprehensive view of English and American literature in outline, as mentioned before, is essential, as well as specific courses dealing with given works to be read both in and out of the classroom, grouped in terms of genre, literary period, content, etc, implying the exposure of students to background information (cultural, historical, biographical, critical, etc.) relevant to the interpretation (or interpretations) of the works in question, and also promoting their further research. It would not be very sensible, and in fact even frivolous, to assume that they have already mastered this knowledge, or that they will acquire it on their own. This option should contemplate, if possible, the participation of students by means of discussions, papers, etc, so that it becomes more than a strict teacher-centred lesson. The selection of the works to be studied implies here also some kind of grading, both in terms of language and literary complexity, especially for those works to be read by all the students.

As for the stylistics option, I suggest it is carried out in two courses, one at a lower level, another, more complex, one or two years later. The lower one should deal primarily with an introductory stylistic analysis of texts, and also with information about research sources, development of reference skills, etc, whereas the second one could be entirely a stylistics course focusing on given literary works to be read in an intensive reading scheme, within the classroom, perhaps at a much slower pace than in the mainstream courses and of course, from the stylistic point of view. Reading outside the classroom, leading to stylistic research on literary works chosen by students, could also be contemplated. Needless to say, co-ordination first of literature teachers and secondly, of language and literature teachers, in aspects such as works to be studied, terminology to be employed, etc, would surely result in more effectiveness.

\section{Notes}

1. It is included in the proposals sent by the universities of Valencia (p. 31), Málaga (p. 34), País Vasco (p. 39), Navarra (p. 47) and Zaragoza (p. 65).

2. See Beckson and Ganz 68, and Sarup 59.

3. This proposal is described by Durant and Fabb.

\section{Works Cited}

Beckson, K. and A. Ganz. «Deconstruction.» Literary Terms: A Dictionary.London: Andre Deustch, 1990.

Brock, Mark N. «The Case for Localized Literature in the ESL Classroom.» English Teaching Forum 23.3 (1990): 22-26. 
Brumfit, C. «Literary Curriculum in World Education.» Literature and the Learner: Methodological Approaches. Ed. R. Carter, R. Walker and C. Brumfit. London: Modern English Publications and The British Council, 1989. 45-49.

and R. A. Carter. Introduction. Literature and Language Teaching. Ed. C. J. Brumfit and R. A. Carter. Oxford: Oxford UP, 1986.

Carter, R., R. Walker and C. Brumfit, eds. Literature and the Learner: Methodological Approaches. London: Modern English Publications and The British Council, 1989.

Collie, J. and S. SlaterLiterature in the Language Classroom. Cambridge: Cambridge UP, 1990.

Consejo de Universidades. Reforma de las enseñanzas universitarias. Título: Filología Inglesa. Secretaría General del Consejo de Universidades, 1988.

Culler, J. Structuralist Poetics. London: Routledge and Kegan Paul, 1975.

. On Deconstruction: Theory and Criticism after Structuralism. Ithaca, N. Y.: Cornell University Press, 1982.

Durant, A. and N. Fabb. "New Courses in the Linguistics of Writing." The Linguistics of Writing. Ed. N. Fabb, D. Attridge, A. Durant and C. McCabe. Manchester: Manchester UP, 1987. 224-240.

Fleck, Ludwik. Entshehung and Entwicklung einer wissenshcaftlichen Tatsache. Frankfurt am Main: Sukhramp Verlag, 1980.

Fowler, R. Linguistics and the Novel. London: Methuen, 1977.

Gower, R. «Can Stylistics Analysis Help the EFL Learner to Read Literature?» ELT Journal 40 (1990): 64-78.

Gréimas, A. J., ed. Essais de sémiotique poétique. The Hague: Mouton, 1979.

Grice, H. P.« Logic and Conversation.» Syntax and Semantics III: Speech Acts. Ed. P. Cole and J. Morgan. New York: Academic Press, 1975.

Halliday, M. A. K. and R. Hasan. Language, Content and Text: Aspects of Language in a Social-Semiotic Perspective. Oxford: Oxford UP, 1989.

Hasan, R. Linguistics, Language and Verbal Art. Oxford: Oxford UP, 1989.

Hawkes, T. Structuralism and Semiotics. London: Methuen, 1977.

Johnson, Barbara. The Critical Difference: Essays in the Contemporary Rhetoric of Reading. Baltimore: The Johns Hopkins UP, 1980.

Krashen, S. Writing: Research, Theory and Applications. Oxford: Pergamon Press, 1984.

Labov, W. Language in the Inner City. Philadelphia: U of Pennsylvannia P, 1972.

Leech, G. A Linguistic Guide to English Poetry. London and New York: Longman, 1969. and M. H. Short. Style in Fiction. London and New York: Longman, 1981.

Littlewood, W. T. «Literature in the School Foreign Language Course.» Literature and Language Teaching. Ed. C. J. Brumfit and R. A. Carter. Oxford: Oxford UP, 1986. 177-84.

Maley, A. «Down From Pedestal.» Literature and the Learner: Methodological Approaches.Ed. R. Carter, R. Walker and C. Brumfit. London: Modern English Publications and The British Council, 1989. 24-29.

Marton, W. Methods in English Language Teaching. London: Prentice Hall, 1988.

Michaels, W. B. «Walden's False Bottoms.» Glyph I: Johns Hopkins Textual Studies. Baltimore: The Johns Hopkins UP,1977. 132-149.

Moody, L. B. The Teaching of Literature in Developing Countries. London: Longman, 1971.

Ohmann, R. «Generative Grammars and the Concept of Literary Style.» Word 20 (1964): 423-39.

Pickett, G. D. «Reading Speed and Literature Teaching.» Literature and Language Teaching.Ed. C. Brumfit and R. A. Carter. Oxford: Oxford UP, 1986. 262-283.

Rosenblatt, L. M. Literature and Exploration. 1938. New York and Dallas: Noble and Noble, 1976. 
Sarup, M. An Introductory Guide to Post-Structuralism and Post-Modernism. London: Harvester Wheatsheaf, 1988.

Scarle, J. R. Speech Acts. Cambridge: Cambridge University Press, 1969.

Short, M. H. and C. Candlin. «Teaching Study Skills for English Literature.» Literature and Language Teaching. Ed. C. J. Brumfit and R. A. Carter. Oxford: Oxford UP, 1986. 89-110. Spitzer, L. Linguistics and Literary History. Princeton, N. J.: Princeton UP, 1948.

Todorov, T. Literature et signification. Paris: Larousse, 1967.

Tompkins, J. T. Introduction. Reader-Response Criticism. Ed. Jane T. Tompkins. Baltimore: The Johns Hopkins UP, 1980. Ix-xvin.

- «The Reader in History: The Changing Shape of Literary Response.» ReaderResponse Criticism. Ed. Jaine T. Tompkins. Baltimore: The John Hopkins UP, 1980. 201-33.

Reader-Response Criticism. Baltimore: The Johns Hopkins UP, 1980.

Ward, D. «Exam Boards 'Sensitive' to GSCE Guinea Pigs.» The Guardian 16 August 1990, int. ed.: 22 . 